IQTISHADIA

12,1

\section{The Characteristics of Responses to Smart City Device Usage, Maqasid Shariah Perspective: The Case of Kota Depok, West Java, Indonesia}

\author{
Dodik Siswantoro \\ Universitas Indonesia
Dodik.siswantoro@ui.ac.id \\ Universitas Indonesia
Dodik.siswantoro@ui.ac.id
}

\begin{abstract}
The research aims to analyze the characteristics of smart city device usage from
maqasid shariah perspective. The smart city device was developed to support users
to fulfill their needs which actually relates to maqasid shariah. Therefore, the higher
rate of smart city device usage will increase the quality of life. This includes such
factors that make people use this device. This research employs the quantitative
method based on the questionnaires distributed to the people of Kota Depok,
Indonesia. This device is supposed to increase the activity level of smart city. In fact,
only few people use smart city device for their needs and purposes. The benefit of the
device is a significant factor to use the smart city device. In addition, not all maqasid
shariah aspects covered in the smart city device of Kota Depok.
Abstract
The research aims to analyze the characteristics of smart city device usage from
maqasid shariah perspective. The smart city device was developed to support users
to fulfill their needs which actually relates to maqasid shariah. Therefore, the higher
rate of smart city device usage will increase the quality of life. This includes such
factors that make people use this device. This research employs the quantitative
method based on the questionnaires distributed to the people of Kota Depok,
Indonesia. This device is supposed to increase the activity level of smart city. In fact,
only few people use smart city device for their needs and purposes. The benefit of the
device is a significant factor to use the smart city device. In addition, not all maqasid
shariah aspects covered in the smart city device of Kota Depok.

Abstract
The research aims to analyze the characteristics of smart city device usage from
maqasid shariah perspective. The smart city device was developed to support users
to fulfill their needs which actually relates to maqasid shariah. Therefore, the higher
rate of smart city device usage will increase the quality of life. This includes such
factors that make people use this device. This research employs the quantitative
method based on the questionnaires distributed to the people of Kota Depok,
Indonesia. This device is supposed to increase the activity level of smart city. In fact,
only few people use smart city device for their needs and purposes. The benefit of the
device is a significant factor to use the smart city device. In addition, not all maqasid
shariah aspects covered in the smart city device of Kota Depok.

Abstract
The research aims to analyze the characteristics of smart city device usage from
maqasid shariah perspective. The smart city device was developed to support users
to fulfill their needs which actually relates to maqasid shariah. Therefore, the higher
rate of smart city device usage will increase the quality of life. This includes such
factors that make people use this device. This research employs the quantitative
method based on the questionnaires distributed to the people of Kota Depok,
Indonesia. This device is supposed to increase the activity level of smart city. In fact,
only few people use smart city device for their needs and purposes. The benefit of the
device is a significant factor to use the smart city device. In addition, not all maqasid
shariah aspects covered in the smart city device of Kota Depok.

Abstract
The research aims to analyze the characteristics of smart city device usage from
maqasid shariah perspective. The smart city device was developed to support users
to fulfill their needs which actually relates to maqasid shariah. Therefore, the higher
rate of smart city device usage will increase the quality of life. This includes such
factors that make people use this device. This research employs the quantitative
method based on the questionnaires distributed to the people of Kota Depok,
Indonesia. This device is supposed to increase the activity level of smart city. In fact,
only few people use smart city device for their needs and purposes. The benefit of the
device is a significant factor to use the smart city device. In addition, not all maqasid
shariah aspects covered in the smart city device of Kota Depok.

Abstract
The research aims to analyze the characteristics of smart city device usage from
maqasid shariah perspective. The smart city device was developed to support users
to fulfill their needs which actually relates to maqasid shariah. Therefore, the higher
rate of smart city device usage will increase the quality of life. This includes such
factors that make people use this device. This research employs the quantitative
method based on the questionnaires distributed to the people of Kota Depok,
Indonesia. This device is supposed to increase the activity level of smart city. In fact,
only few people use smart city device for their needs and purposes. The benefit of the
device is a significant factor to use the smart city device. In addition, not all maqasid
shariah aspects covered in the smart city device of Kota Depok.

Abstract
The research aims to analyze the characteristics of smart city device usage from
maqasid shariah perspective. The smart city device was developed to support users
to fulfill their needs which actually relates to maqasid shariah. Therefore, the higher
rate of smart city device usage will increase the quality of life. This includes such
factors that make people use this device. This research employs the quantitative
method based on the questionnaires distributed to the people of Kota Depok,
Indonesia. This device is supposed to increase the activity level of smart city. In fact,
only few people use smart city device for their needs and purposes. The benefit of the
device is a significant factor to use the smart city device. In addition, not all maqasid
shariah aspects covered in the smart city device of Kota Depok.

Abstract
The research aims to analyze the characteristics of smart city device usage from
maqasid shariah perspective. The smart city device was developed to support users
to fulfill their needs which actually relates to maqasid shariah. Therefore, the higher
rate of smart city device usage will increase the quality of life. This includes such
factors that make people use this device. This research employs the quantitative
method based on the questionnaires distributed to the people of Kota Depok,
Indonesia. This device is supposed to increase the activity level of smart city. In fact,
only few people use smart city device for their needs and purposes. The benefit of the
device is a significant factor to use the smart city device. In addition, not all maqasid
shariah aspects covered in the smart city device of Kota Depok.

Abstract
The research aims to analyze the characteristics of smart city device usage from
maqasid shariah perspective. The smart city device was developed to support users
to fulfill their needs which actually relates to maqasid shariah. Therefore, the higher
rate of smart city device usage will increase the quality of life. This includes such
factors that make people use this device. This research employs the quantitative
method based on the questionnaires distributed to the people of Kota Depok,
Indonesia. This device is supposed to increase the activity level of smart city. In fact,
only few people use smart city device for their needs and purposes. The benefit of the
device is a significant factor to use the smart city device. In addition, not all maqasid
shariah aspects covered in the smart city device of Kota Depok.

Abstract
The research aims to analyze the characteristics of smart city device usage from
maqasid shariah perspective. The smart city device was developed to support users
to fulfill their needs which actually relates to maqasid shariah. Therefore, the higher
rate of smart city device usage will increase the quality of life. This includes such
factors that make people use this device. This research employs the quantitative
method based on the questionnaires distributed to the people of Kota Depok,
Indonesia. This device is supposed to increase the activity level of smart city. In fact,
only few people use smart city device for their needs and purposes. The benefit of the
device is a significant factor to use the smart city device. In addition, not all maqasid
shariah aspects covered in the smart city device of Kota Depok.

Abstract
The research aims to analyze the characteristics of smart city device usage from
maqasid shariah perspective. The smart city device was developed to support users
to fulfill their needs which actually relates to maqasid shariah. Therefore, the higher
rate of smart city device usage will increase the quality of life. This includes such
factors that make people use this device. This research employs the quantitative
method based on the questionnaires distributed to the people of Kota Depok,
Indonesia. This device is supposed to increase the activity level of smart city. In fact,
only few people use smart city device for their needs and purposes. The benefit of the
device is a significant factor to use the smart city device. In addition, not all maqasid
shariah aspects covered in the smart city device of Kota Depok.
\end{abstract}

Keywords:

Smart city, Characteristics, Achievement, Device, Internet.

\section{INTRODUCTION}

The issue of smart city has been tremendously blast in Indonesia. This has become an interesting issue in Indonesia since 2010 as it gives benefits to the planning and development of a city in Indonesia. However, although in practice the issue has been scientifically and technologically developed, not much has been discussed in social aspect, especially in the Islamic perspective. Thus, there is a gap on this case for smart city study.

Smart city has become a standard for city development all over the world. It can ease citizen to fulfill their need and increase their life quality. The device has been developed by a high technology to support the activity of the people in the city. This can be basic needs which can be also viewed from maqasid shariah as the basic principles in Islam.

The objective of this research is to analyze the data on the characteristics Vol. 12 (1) 2019 PP. $30-40$ P-ISSN: $1979-0724$ E-ISSN: 2502 - 3993 DOI: 10.21043 /iqtishadia.v12i1.4571

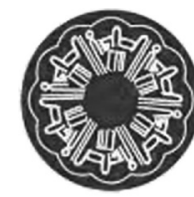
of smart city device obtained from responses of the people in that city and from maqasid shariah perspective. It starts from related reference discussions 
and supporting theories. Description on research methodology and analysis is intended to see the characteristics and supporting theories.

\section{LITERATURE REVIEW}

Most literatures on smart city are scientifically and technologically reviewed. They have based their discussion on systematic technology to create efficient economy and better information system in a city. However, in public sector, only few researchers have particularly discussed this. Although in practice each local government already has smart city issues, public sector has not dealt with such issues. Thus, this paper would like to bridge the gap and discuss smart city in public sector perspective as well as the maqasid shariah.

Smart city is defined differently based on context and cases in one place. This paper defines smart city in different perspectives of researchers. In general, smart city uses high technology to ease and to accommodate the need of citizen in one city. However there is no minimum standard one city can be called as smart city although it has applied high technology in servicing people.

Maqasid shariah is the objective of the implementation on shariah whereby shariah can be implied on general term. According Zahrah (2005), maqasid shariah is not only consisting of five aspects such as (a) necessity to preserve religion, (b) life, (c) intellect, (d) progeny, and (e) wealth, but it also covers to enhance the education and to uphold justice. Therefore the smart city goal should be in line with the maqasid shariah as they have common goal. The achievement of smart city goal can be implicitly included also of maqasid shariah which can be generally applied. However, this research is rare and may be new on this topic. Maqasid shariah can be included implicitly as aspects to be concerned with the smart city.

Adapa (2018) studied a smart city and cleaner production issues in India. He assumed that a smart city comprises more than the six dimensions of a smart economy, smart people, smart governance, smart mobility, a smart environment and smart living. Such other models as quadruple helix, society, and fourth element can be added. He found that many activities are required to achieve the status of smart city and cleaner production. This also depends on the characteristic of a city in one country. Accordingly, the definition of smart city changes over time.

Jin et al. (2016) stated that Internet of Things (IoT) gets everything and everyone connected. It merges information technology (IT) and physical 
IQTISHADIA

12,1 life and support smart city operation. They used 3 approaches: (a) contentbased approach, promoting similar item (b) collaborative-based approach, recommendation item and (c) hybrid approach, mix approach. This application will assist users to find recommended places. Thus, this would be the basis of this research.

Papa, et al. (2018) studied the attitude-mediated intention of using device (healthcare smart wearable healthcare-SWH) in India. The result shows that attitude (AA) significantly affects intention to use (IU), while attitude has such various factors as perceived usefulness (PU-significant), intrusiveness (not significant), comfort (not significant), and perceived ease of use (PEU-significant). This shows that people more likely to be comfortable when they gain benefits and ease in using the device. Gai, et al. (2018) urge the use of financial technology to speed up development, in case of smart city and cloud computing.

Walravens (2015) has created some indicators for smart city application which means getting smarter for any quality of life. They include (a) value network (good governance and stakeholder management), (b) technical architecture (technology governance and public data ownership), (c) financial architecture (return on public investment and public partnership model), and (d) value proposition (public value creation and public value evaluation). The problem of providing an application for smart city is the complexity of city activities. That is why qualitative measurements are needed. Meanwhile, Walravens (2015) a studied the usefulness of smart city device to develop the city of Brussels in Belgium. It can improve the activity of the city for economic development.

Thus, the hypotheses for this research are:

H1: The attitude towards the adoption of Depok Smart city device is dependent on Perceived ease of use (POU).

H2: The attitude towards the adoption of Depok Smart city device is dependent on Perceived usefulness (PU)

H3: The Behavioral Intention to use Depok Smart city device is dependent on the attitude -towards adoption (AA) of Depok Smart city device.

H4: The PU of Depok Smart city device is dependent on POU 
$\mathrm{H}_{5}$ : The Behavioral Intention to use (IU) Depok Smart city device is dependent on the PU.

\section{METHOD}

This research employs the survey-based quantitative method. The questionnaires were sent through Whatsapp to the users who stay in Kota Depok or actively visit Kota from 14 to17 May 2018. The respondents are 43 users of android smartphones.

The research refers to framework model of Papa et al. (2018) which applies variance-based PLS SEM and small sample size. Due to insignificance, such variables as intrusiveness and comfort are excluded from this research. In addition, observed variables are reduced and modified to fit the research context. List of statements can be seen in appendix 1. Beside that, impact is added as it has significant effect in the previous model (see figure 1 in dash arrow). The analysis of maqasid shariah is based on the aspect of smart city device component and the response of respondents.

Figure 1. Hypothesis model

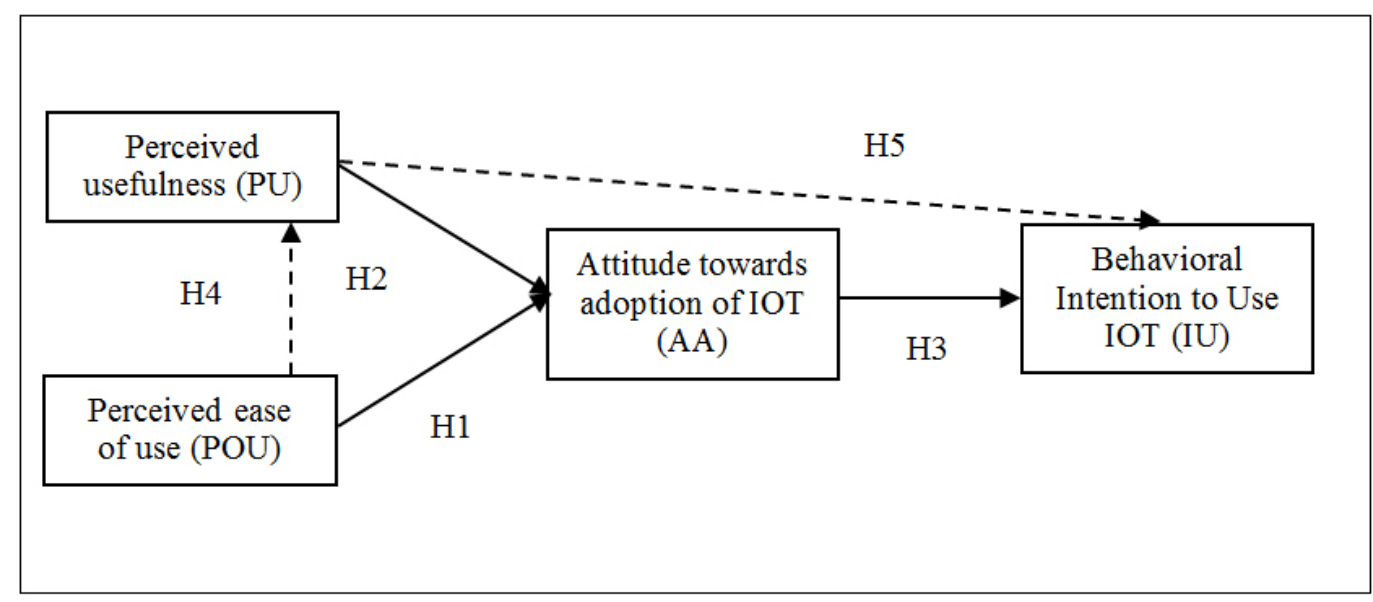

Source: Author

The smart city device includes information about tourism, place (restaurant, banks \& ATM, pray, hospital and police), news, and complaints. Citizen can get information on nearest places for specific information and buildings. People who are visiting kota Depok also benefited from this device.

\section{ANALYSIS}

The analysis starts from crosstab analysis to enrich the perspectives. Male and female respondents relatively have similar response to the know-how of the Depok smart city device. Approximately, only $40 \%$ of the female 
IQTISHADIA

12,1

34

and male respondents are familiar with the Depok smart city (see table 1). Male respondents have bigger percentage usage of Depok smart city device compared to female respondent (23.1\% and $13.3 \%$, respectively- table 2). But it is still below 50\% usage. Male respondents may have needed of this device.

Table 1. Crosstab of Sex and Know-how of Smart City Device

\begin{tabular}{ccccc}
\hline & & \multicolumn{3}{c}{ Know-how } \\
\cline { 2 - 5 } & & No & Yes & Total \\
\hline \multirow{4}{*}{ Sex } & Male & 8 & 5 & 13 \\
\cline { 2 - 5 } & $\%$ & 61.5 & 38.5 & 100 \\
\cline { 2 - 5 } & Female & 18 & 12 & 30 \\
\cline { 2 - 5 } & $\%$ & 60 & 40 & 100 \\
\hline & Total & 26 & 17 & 43 \\
\hline
\end{tabular}

Source: Data

Table 2. Crosstab Sex and Use of Smart City Device

\begin{tabular}{ccccc}
\hline & & \multicolumn{3}{c}{ Use } \\
\cline { 2 - 5 } Sex & No & Yes & Total \\
\hline \multirow{4}{*}{ Male } & 10 & 3 & 13 \\
\cline { 2 - 5 } & $\%$ & 76.9 & 23.1 & 100 \\
\cline { 2 - 5 } & Female & 26 & 4 & 30 \\
\cline { 2 - 5 } & $\%$ & 86.7 & 13.3 & 100 \\
\hline & Total & 36 & 7 & 43 \\
\hline
\end{tabular}

Source: Data

Undergraduates have the biggest percentage of Depok smart city device usage (26.3\%), while graduates account for only $12.5 \%$, followed by high school graduates (8.3\%). The pattern of smart city device is random for education graduate level.

Table 3. Crosstab Education and Use of Smart City Device

\begin{tabular}{ccccc}
\hline & & \multicolumn{3}{c}{ Use } \\
\cline { 2 - 5 } & & No & Yes & Total \\
\hline & Diploma & 4 & 0 & 4 \\
\cline { 2 - 5 } Education & $\%$ & 100 & 0 & 100 \\
\cline { 2 - 5 } & S1 & 14 & 5 & 19 \\
\cline { 2 - 5 } & $\%$ & 73.7 & 26.3 & 100 \\
\cline { 2 - 5 } & S2/S3 & 7 & 1 & 8 \\
\cline { 2 - 5 } & $\%$ & 87.5 & 12.5 & 100 \\
\cline { 2 - 5 } & High School & 11 & 1 & 12 \\
\hline$\%$ & 91.7 & 8.3 & 100 \\
\hline & Total & 36 & 7 & 43 \\
\hline
\end{tabular}

Source: Data 
Users of Depok Smart city device are mostly middle-aged (around 30\% for 31-40 years old and 29\% for 41-50 years old). Teen agers (20-30 years old) are not interested in using this device. This may be caused by the fact that they do not need this device in that age.

Table 4. Crosstab Age and Use of Smart City Device

\begin{tabular}{ccccc}
\hline & & \multicolumn{3}{c}{ Use } \\
\cline { 2 - 5 } & & No & Yes & Total \\
\hline \multirow{5}{*}{ Age (year) } & 1 & 0 & 1 \\
\cline { 2 - 5 } & $\%$ & 100 & 0 & 100 \\
\cline { 2 - 5 } & $20-30$ & 22 & 2 & 24 \\
\cline { 2 - 5 }$\%$ & 91.7 & 8.3 & 100 \\
\cline { 2 - 5 } & $31-40$ & 7 & 3 & 10 \\
\cline { 2 - 5 } & $41-50$ & 5 & 2 & 700 \\
\cline { 2 - 5 } & $\%$ & 71.4 & 28,6 & 100 \\
\cline { 2 - 5 } & $>51$ & 1 & 0 & 1 \\
\hline$\%$ & 100 & 0 & 100 \\
\hline & Total & 36 & 7 & 43 \\
\hline
\end{tabular}

Source: Data

Response to the Depok Smart city suggests that it can solve any issues and may be appropriate to solve complaint in Depok Smart city (agreement response rate of $70 \%$ ). They agree that this device can solve the complaints of the citizens. This issue is similar to Adapa's finding (2018), which suggests that the use of Depok Smart city device can increase comfort to citizen.

Table 5. Crosstab of Complain Issues and Complain Online of Smart City Device

\begin{tabular}{ccccc}
\hline & & \multicolumn{3}{c}{ Complain Online } \\
\cline { 2 - 5 } & & No & Yes & Total \\
\hline \multirow{7}{*}{ Not very agree } & 0 & 1 & 1 \\
\cline { 2 - 5 } & $\%$ & 0 & 100 & 100 \\
\cline { 2 - 5 } & Not agree & 5 & 1 & 6 \\
\cline { 2 - 5 } & $\%$ & 83.3 & 16.7 & 100 \\
\cline { 2 - 5 } & Neutral & 13 & 3 & 16 \\
\cline { 2 - 5 } & $\%$ & 81.3 & 18.8 & 100 \\
\cline { 2 - 5 } & Agree & 3 & 7 & 10 \\
\cline { 2 - 5 } & $\%$ & 20 & 70 & 100 \\
\cline { 2 - 5 } & Very Agree & 2 & 8 & 10 \\
\hline$\%$ & 20 & 80 & 100 \\
\hline & Total & 23 & 20 & 43 \\
\hline
\end{tabular}

Source: Data 
IQTISHADIA

12,1

From this response, we can see that most respondents may have aligned to maqasid shariah as putting hospital, bank, pray, and police as higher priority. Hospital and life can be included as necessity to life and pray for necessity to preserve religion. Islamic bank location is also informed in the device, but not for other Islamic financial institutions such as Islamic insurance, leasing and pawn. Other places for investing in Islamic bond and capital markets should also be informed.

Necessity to preserve intellect is suggested by respondents as this information is also important. In kota Depok, there are many Islamic schools from elementary until high school. Only necessity to preserve progeny is not concerned by respondents. Kota Depok has the highest rate of divorce, in 2017 there was over 5000 cases. In 2018, everyday 25 cases of divorce proposal came into the court, only $1 \%$ which can be solved and mediated by the court (Republika, 2018). Therefore, this device should give information on how to manage marriage in harmony and location for marriage conflict consultation.

Table 5. Descriptive Statistic of Place Preference

\begin{tabular}{lcccc}
\hline \multicolumn{1}{c}{ Place } & Min & Max & Mean & SD \\
\hline Hospital & 3 & 5 & 4.35 & .813 \\
\hline Bank & 3 & 5 & 4.33 & .778 \\
\hline Pray & 1 & 5 & 4.30 & .939 \\
\hline Police & 3 & 5 & 4.23 & .868 \\
\hline Complaints & 2 & 5 & 4.19 & .906 \\
\hline Restaurants & 2 & 5 & 4.09 & .811 \\
\hline Tourism & 3 & 5 & 3.98 & .771 \\
\hline News & 1 & 5 & 3.56 & 1.031 \\
\hline
\end{tabular}

Source: Data

The analysis of affecting variables can be described in Smart PLS tool. Based on Papa et al. (2018), it shows that Perceived Usefulness (PU) has significant effect on Attitude towards adoption of IOT (AA). Meanwhile, 
Perceived ease of use (PEU) does not have any significant effect on Attitude towards adoption of IOT (AA), yet it affects significantly Intention to Use (IU). PEU has two indicators which show that the application is easy to use and clearly understandable, but it still cannot affect attitude towards adoption.

Figur 1. Hypothesis model

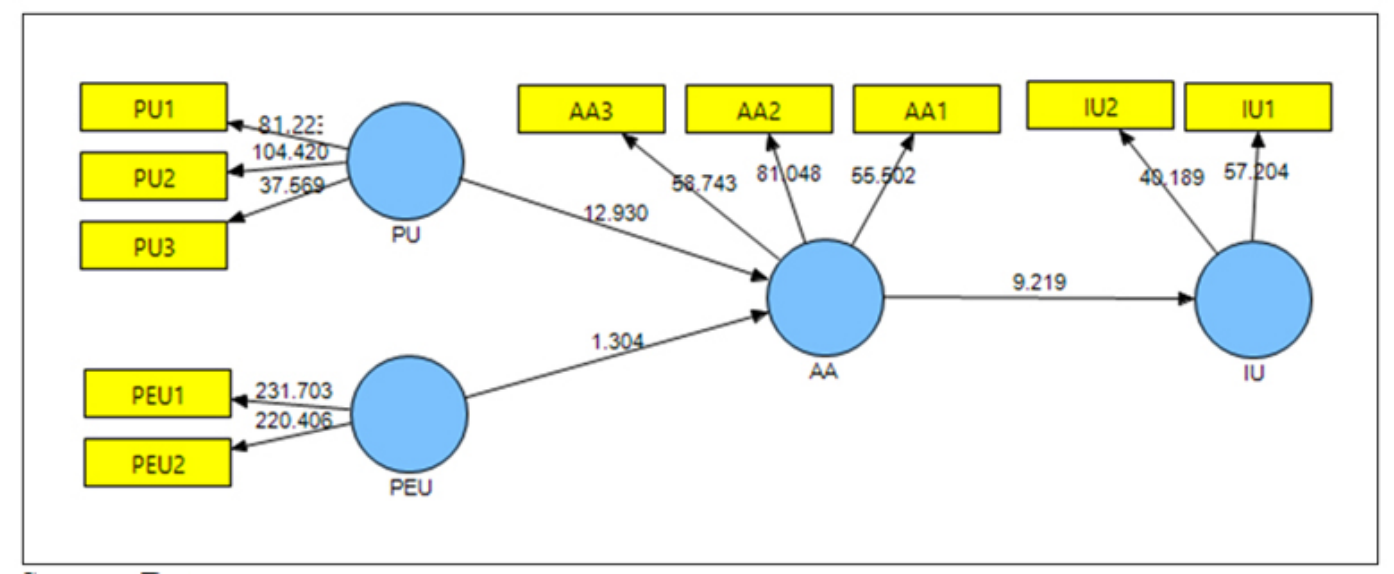

Then, the model is the modified version of the basic model of technology acceptance model (TAM) by Davis (1989). A similar model was developed by Koch et al. (2011) and Gavrilova (2009). However, the modified and updated model has been researched by many authors. From new connection in figure 2, only connection of Perceived ease of use (PEU) to Perceived Usefulness (PU) has significant effect rather than Perceived Usefulness (PU) to Intention to Use (IU). This new connection has caused lower significant number for Attitude towards adoption of IOT (AA) to Intention to Use (IU). The Perceived ease of use (PEU) is still not significant to Attitude towards adoption of IOT (AA). Users may find other alternative information rather than merely using this device.

The ease of use Depok Smart city application can improve Perceived Usefulness (PU) of users. As the application is assumed to be easy, it can result in the usefulness of users. Detail of statistic test can be seen in the appendix 2, table 8 for current statistic test, while table 9 for new model. Abu-Issa, et al. (2017) also concerns that the issue of benefits is majorly effect to the application of smart city device. The issue of life quality improvement was addressed in Walravens' study (2015) while the issue of economic benefits was addressed in Walravens' another study (2015a). This issue may be also be reflected by the incompleteness of maqasid shariah components such as information for necessity to preserve intellect and progeny. Smart city should be covered aspect which is needed by citizen of kota Depok. 
IQTISHADIA

12,1

The new model can increase the values of AVE, Composite Reliability, R Square, Cronbach's Alpha, and Communality for IU. While, AA only increases at R Square. On the other hand, PEU decreased in AVE, Composite Reliability, and Communality. However, the new model proves to be better as it gives increasing value for the last variable.

Tabel 6. Data of Variable Relationship

\begin{tabular}{ccccccc}
\hline AVE & $\begin{array}{c}\text { Compos- } \\
\text { ite Reli- } \\
\text { ability }\end{array}$ & R Square & $\begin{array}{c}\text { Cron- } \\
\text { bach's } \\
\text { Alpa }\end{array}$ & Communality & Redundansy \\
\hline AA & 0.885477 & 0.958666 & 0.904554 & 0.935282 & 0.885477 & 0.127784 \\
\hline IU & 0.878100 & 0.935092 & 0.579105 & 0.861395 & 0.878100 & 0.507307 \\
\hline PEU & 0.976680 & 0.988203 & & 0.976125 & 0.976680 & \\
\hline PU & 0.900974 & 0.964638 & & 0.944727 & 0.900974 & \\
\hline
\end{tabular}

Tabel 7. Data Of New Model of Variable Relationship

\begin{tabular}{ccccccc}
\hline & AVE & $\begin{array}{c}\text { Composite } \\
\text { Reliability }\end{array}$ & R Square & $\begin{array}{c}\text { Cron- } \\
\text { bach's } \\
\text { Alpa }\end{array}$ & $\begin{array}{c}\text { Communal- } \\
\text { ity }\end{array}$ & Redundansy \\
\hline AA & 0.885477 & 0.958666 & 0.904663 & 0.935282 & 0.885477 & 0.127251 \\
\hline IU & 0.878100 & 0.935107 & 0.579561 & 0.861395 & 0.878125 & 0.502677 \\
\hline PEU & 0.976680 & 0.988203 & & 0.976125 & 0.976680 & \\
\hline PU & 0.900974 & 0.964635 & 0.788553 & 0.944727 & 0.900964 & 0.709613 \\
\hline
\end{tabular}

\section{CONCLUSION}

The characteristics of Depok Smart city can be found in the middle-aged users. They include the education level in which undergraduates prefer using this application. Most respondents expect that the device can solve any 
complaint. Incomplete of maqasid shariah aspects may cause some variables are not significant to others.

All hypotheses are consistent to previous researches except for Perceived ease of use (PEU) to Attitude towards adoption of IOT (AA). Meanwhile, the additional hypothesis (Perceived Usefulness (PU) to Intention to Use (IU) of Responses was not supported. This shows that users do not directly have intention to use the device for their need.

\section{References}

Abu-Issa, A., Nawawreh, H., Shreteh, L., Salman, Y., Hassouneh, Y., Tumar, I., and Hussein, M. (2017). A smart city mobile application for multitype, proactive, and context-aware recommender system. ICET2017.

Adapa, S. (2018). Indian smart cities and cleaner production initiativesIntegrated framework and recommendations. Journal of Cleaner Production Vol 172. 3351-3366.

Davis, F. D. (1989). Perceived usefulness, perceived ease of use, and user acceptance of information technology. MIS Quarterly Vol 13 (3). 319340.

Gai, K., Qiu, M., and Sun, X. 92018). A survey on FinTech. Journal of Network and Computer Applications Vol 103. 262-273.

Gavrilova, M., L. (2009). Adaptive Computation Paradigm in Knowledge Representation: Traditional and Emerging Applications. International Journal of Software Science and Computational Intelligence Vol 1(1). 1-13.

Jin, D., Hannon, C., Li, Z., Cortes, P., Ramaraju, S., Burgess, P., Buch, N., and Shahidehpour, M. (2016). Smart street lighting system: A platform for innovative smart city applications and a new frontier for cybersecurity. The Electricity Journal Vol 29. 28-35.

Koch, S., Toker, A., and Brulez, P. (2011). Extending the Technology Acceptance Model with perceived community characteristics. Information Research, 16(2) at http://www.informationr.net/ir/162/paper478.html.

Papa, A., Mital, M., Pisano, P., and Giudice, M. D. (2018). E-health and wellbeing monitoring using smart healthcare devices: An empirical investigation. Technological Forecasting \& Social Change Vol x(x): $\mathrm{X}-\mathrm{X}$

Republika. (2018). Perceraian di Kota Depok Cukup Tinggi, Mengapa? At https://www.republika.co.id/berita/nasional/jabodetabeknasional/18/11/o3/phmhzk440-perceraian-di-kota-depok-cukuptinggi-mengapa (accessed at 3 December 2018) 
IQTISHADIA

12,1

40

Walravens, N. (2015a). Mobile city applications for Brussels citizens: Smart
City trends, challenges and a reality check. Telematics and Informatics
Vol 32. 282-299.

Walravens, N. (2015a). Mobile city applications for Brussels citizens: Smart
City trends, challenges and a reality check. Telematics and Informatics
Vol 32. 282-299.

Walravens, N. (2015a). Mobile city applications for Brussels citizens: Smart
City trends, challenges and a reality check. Telematics and Informatics
Vol 32. 282-299.

Zahrah, M. A. ( 2005). Ushul Fiqh. Jakarta: Pustaka Firdaus.

Walravens, N. (2015). Qualitative indicators for smart city business models: The case of mobile services and applications. Telecommunications Policy Vol 39. 218-240. 